\title{
PENINGKATAN PEMBELAJARAN TEMATIK MENULIS PANTUN BERBANTUAN PENDEKATAN SCIENTIFIC PADA SISWA KELAS V SDN 002 SAMARINDA TAHUN AJAR 2016/2017
}

\author{
Hety Diana Septika ${ }^{1}$, Mohammad Ilyas ${ }^{2}$ \\ Universitas Mulawarman ${ }^{1}$, Universitas Mulawarman ${ }^{2}$ \\ Pos-el: hety.diana@fkip.unmul.ac.id ${ }^{1}$, milyas@yahoo.com²
}

\begin{abstract}
ABSTRAK
Penelitian ini dilatarbelakangi adanya kesulitan penerapan pembelajaran menulis dalam kurikulum 2013 yang mengalami kesenjangan. Kesulitan penerapan K13 dengan banyaknya penilaian dalam K13 menyebabkan para guru enggan menggunakan pembelajaran K13. Pembelajaran Bahasa Indonesia dalam K2013 memiliki peranan penting salah satunya keterampilan menulis. Salah satu keterampilan yang diajarkan di Sekolah Dasar yaitu menulis pantun. Menulis pantun dirasakan penting untuk diajarkan karena selain sebagai warisan budaya namun juga perlu pelestarian dan dikenal oleh anak.khususnya siswa Sekolah Dasar.
\end{abstract}

Kata kunci : Menulis, Pantun, Pendekatan Scientifik

\section{ABSTRACT}

This research is motivated by the difficulty of applying writing learning in the 2013 curriculum which experiences gaps. The difficulty of applying K13 with the many assessments in K13 has made teachers reluctant to use K13 learning. Learning Indonesian in K2013 has an important role, one of which is writing skills. One of the skills taught in elementary schools is poetry writing. Poetry writting is important to be taught because in addition to being a cultural heritage, it also needs to be preserved and known by children especially Elementary School.

Keywords: Writing, Poetry, Scientific Aproaches

\section{PENDAHULUAN}

Tahap awal pelaksanaan Kurikulum 2013 yang dilakukan secara tergesa-gesa menciptakan kondisi yang kurang menguntungkan bagi guru. Guru sebagai pelaksana Kurikulum 2013 mengalami kebingungan karena adanya perubahan yang sangat krusial dalam pembelajaran. Perubahan dari pembelajaran yang menggunakan pendekatan bidang studi ke pendekatan tematik terpadu pada mulanya hanya untuk kelas rendah Sekolah Dasar kelas I-III, Kemudian diubah dan diberlakukan pada seluruh kelas di SD. Pada kurikulum
KTSP, pendekatan pembelajaran tematik terpadu berbasis membaca, menulis, dan berhitung kemudian diubah menjadi pendekatan tematik terpadu dan pendekatan scientific pada kurikulum 2013.

Saat ini, yang menjadi masalah guru dalam pembelajaran tematik adalah bagaimana melaksanakan pembelajaran tematik yang sesuai dengan kurikulum 2013. Untuk meningkatkan kemampuan menyusun perencanaan pembelajaran tematik, guru akan diberi contoh mendesain rencana pelaksanaan pembelajaran yang sesuai dengan model 
pembelajaran tematik scientific. Demikian pula dalam pelaksanaannya, guru mendapat bimbingan melakukan praktik pembelajaran tematik scientific yang sesuai dengan Kurikulum 2013.

Pembelajaran Bahasa Indonesia dalam Kurikulum 2013 adalah pembelajaran berbasis teks. Teks di sini merupakan sarana lisan dan tertulis sebagai bentuk wadah komunikasi. Selain itu Pembelajaran Bahasa Indonesia yang selalu diajarkan pada setiap jenjang mencakup empat kegiatan berbahasa yaitu mendengarkan, berbicara, membaca dan menulis. Keempat kegiatan berbahasa tersebut perlu diajarkan dengan baik mengingat siswa sekolah dasar perlu memahami dan terampil dalam mengusai semua keterampilan Berbahasa Indonesia.

Keterampilan Berbahasa Indonesia terdiri atas empat yaitu keterampilan mendengarkan, keterampilan berbicara, keterampilan membaca dan keterampilan menulis. Salah satu keterampilan berbahasa yang penting yaitu keterampilan menulis.

Menurut Tarigan (2008:22) menulis ialah menurunkan atau melukiskan lambang-lambang grafik yang menggambarkan suatu bahasa yang dipahami oleh seseorang, sehingga orang lain dapat membaca lambang-lambang grafik tersebut jika telah memahami bahasa dan gambaran grafik. Dalman (2015:4) berpendapat bahwa menulis adalah proses penyampaian pikiran, angan-angan, perasaan dalam bentuk lambang/tanda/tulisan yang bermakna. Hal ini sejalan dengan pendapat Heaton (1975:127) Menulis adalah kegiatan menyusun kata-kata kalimat secara benar sesuai dengan kaidah tata bahasa kemudian menghubung-hubungkan kalimat tersebut sehingga terbentuk suatu tulisan yang saling berhubungan yang dapat mengkomunikasikan pikiran dan ide penulis tentang suatu topik

Berdasarkan pengertian di atas disimpulkan bahwa menulis adalah kegiatan mengungkapkan gagasan melalui lambang-lambang grafik mulai dari menyusun kata kalimat sesuai dengan kaidah tata bahasa yang kemudian menghubungkan kalimat sehingga membentuk tulisan yang memiliki suatu ide, pemikiran dan topik tertentu.

Keterampilan menulis merupakan salah satu keterampilan berbahasa yang dipelajari oleh siswa di sekolah. Melalui keterampilan menulis, siswa dituntut untuk kreatif dan aktif dalam berpikir dan beraktifitas sebanyak mungkin menuangkan ide-ide yang dimilikinya ke dalam bahasa tulis. Menulis merupakan kegiatan yang mengasyikkan bahkan menulis bisa disebutkan sebagai kegiatan kreatif.

Kemampuan menulis tidak diperoleh secara alamiah, namun perlu dilalui dari proses belajar mengajar. Proses di sini dimaksud harus dilakukan secara berkesinambungan sejak sekolah dasar. pembelajaran menulis perlu mendapat perhatian khususnya di Sekolah Dasar karena kemampuan menulis ini diharapkan di jenjang berikutnya kemampuan menulis siswa mampu menghasilkan karya tulisan yang produktif di masa yang akan datang.

Salah satu pembelajaran menulis yang diajarkan pada jenjang Sekolah Dasar yaitu menulis pantun. Pantun merupakan salah satu jenis karya sastra lama yang mengakar di budaya masyarakat. Lazimnya puisi hanya terdiri atas 4 larik (baris) bersajak ab-ab atau aa-aa. Pada awal mulanya pantun merupakan sastra lisan, tapi kini pantun juga ada dalam 
bentuk tulisan. Keseluruhan bentuk pantun hanyalah berupa sampiran dan isi. Sampiran terletak pada baris pertama dan kedua dan biasanya tidak berhubungan secara langsung dengan bagian kedua serta biasanya hanya mengantarkan rima/ sajak. Hal ini sejalan dengan pendapat Pantun merupakan puisi lama yang memiliki ciri bersajak $a-b-a-b$, tiap bait terdiri dari empat baris, dua baris sampiran dan dua baris isi (Suryaman dan Wiyatmi, 2012: 77). Kerap kali berkaitan dengan alam (menceritakan budaya agraris masyarakat pendukungnya). Baris ketiga dan keempat ialah bagian isi yang merupakan tujuan dari puisi tersebut.

Suroto (1989:44-45) membagi pantun menjadi dua bagian yaitu menurut isinya dan menurut bentuknya atau susunannya. Menurut isinya: (1) pantun anak-anak biasanya berisi permainan, (2) pantun muda mudi biasanya berisi percintaan, (3) pantun orang tua biasanya berisi nasihat atau petuah. Itulah sebabnya pantun ini disebut juga pantun nasihat, (4) pantun jenaka biasanya berisi sindiran sebagai bahan kelakar, (5) pantun teka teki. Menurut bentuknya atau susunannya: (1) pantun berkait, yaitu pantun yang selalu berkaitan antara bait satu dengan bait kedua, bait kedua dengan bait ketiga dan seterusnya. Adapun susunan kaitannya adalah baris kedua bait pertama menjadi baris pertama pada bait kedua, baris keempat bait pertama dijadikan baris ketiga pada bait kedua dan seterusnya. (2) pantun kilat, sering disebut juga karmina, ialah pantun yang terdiri atas dua baris, baris pertama merupakan sampiran sedangkan baris kedua merupakan isi.

Pada jenjang Sekolah Dasar, pantun sendiri juga telah banyak diketahui dan didengar oleh siswa sekolah dasar, dan juga diajarkan pada mata pelajaran bahasa
Indonesia, namun ternyata didapati banyak anak yang sekadar tahu tapi tidak bisa membuat dan menulisnya dengan benar. Berdasarkan hasil mengkaji dari kondisi di SDN 002 Samarinda dan hasil belajar siswa dalam kegiatan belajar mengajar, ternyata penguasaan materi pembelajaran menulis pantun beberapa orang peserta didik yang telah diberikan belum sepenuhnya dapat mencapai persentase ketuntasan yang telah ditetapkan.

Berdasarkan latar belakang tersebut, maka tujuan penelitian yang dicapai yaitu untuk mendeskripsikan hasil peningkatan pembelajaran tematik menulis pantun dengan pendekatan scientific pada tema organ peredaran darah hewan dan manusia di kelas V SDN 002 Samarinda yang dilakukan pada semester ganjil tahun ajar2016/2017.

\section{METODE PENELITIAN}

Penelitian ini merupakan penelitian tindakan kelas yang dilaksanakan selama dua siklus pada SDN 002 Samarinda tahun ajar 2016/2017. Subjek dalam penelitian ini adalah guru dan siswa kelas $\mathrm{V}$ dengan jumlah siswa 27 siswa.

Teknik pengumpulan data dalam penelitian tindakan kelas ini dilakukan dengan observasi, wawancara, tes, dan kajian dokumen. Teknik analisis data menggunakan analisis model interaktif yang terdiri dari pengumpulan data, reduksi data, penyajian data, serta penarikan kesimpulan. Prosedur penelitian yang dilakukan menggunakan model siklus yang terdiri dari perencanaan, tindakan, penamatan dan refleksi. Penelitian ini dilakukan dalam dua siklus setiap siklus terdiri dari dua pertemuan. 


\section{HASIL DAN PEMBAHASAN}

Pada Siklus 1 telah dilaksanakan pembelajaran menulis pantun dengan menggunakan pendekatan scientific pada tema organ peredaran darah hewan dan manusia di kelas V SDN 002 Samarinda menunjukkan peningkatan. Hasil tersebut dapat dilihat dari tabel berikut.

Tabel 1. Rekapitulasi hasil tes formatif siklus 1 menulis pantun

\begin{tabular}{|l|l|c|c|c|c|}
\hline No & $\begin{array}{c}\text { Katego } \\
\text { ri }\end{array}$ & Skor & $\begin{array}{c}\text { Fre } \\
\text { kue } \\
\text { nsi }\end{array}$ & $\begin{array}{c}\text { Juml } \\
\text { ah } \\
\text { Nilai }\end{array}$ & \% \\
\hline 1 & $\begin{array}{l}\text { Sangat } \\
\text { baik }\end{array}$ & $\begin{array}{c}90- \\
100\end{array}$ & - & - & - \\
\hline 2 & Baik & $\begin{array}{c}76- \\
89\end{array}$ & 12 & 941 & $\begin{array}{c}32,4 \\
\%\end{array}$ \\
\hline 3 & Cukup & $68-$ & 3 & 205 & $8,1 \%$ \\
\hline 4 & Kurang & $0-67$ & 22 & 1400 & $\begin{array}{c}59,45 \\
\%\end{array}$ \\
\hline \multicolumn{2}{|l|}{ Jumlah } & & 37 & 2546 & 100 \\
\hline \multicolumn{2}{|l|}{ Rata-rata } & & & 68,81 & \\
\hline
\end{tabular}

Berdasarkan data table1 hanya 12 $(32,4 \%)$ siswa termasuk dalam kategori baik dan ada $3(8,1 \%)$ siswa yang termasuk dalam kategori cukup. Sebanyak 22 $(59,45 \%)$ siswa termasuk dalam kategori kurang dan dikatakan belum memenuhi KKM. Nilai rata-rata kelas pada siklus I sudah memenuhi indikator keberhasilan yang ditentukan yaitu rata-rata kelas $\geq 67$. Nilai siswa pada siklus I masih perlu ditingkatkan dan diperbaiki kekurangankekurangannya agar dapat mencapai indikator keberhasilan yang telah di tentukan.

Tabel 2. Hasil Analisis Ketuntasan Belajar Siswa Kelas V B Siklus I

\begin{tabular}{|l|l|c|c|}
\hline No & \multicolumn{1}{|c|}{ Kategori } & Jumlah & $\%$ \\
\hline 1 & Tuntas & 15 & 40,55 \\
\hline 2 & $\begin{array}{l}\text { Belum } \\
\text { Tuntas }\end{array}$ & 22 & 27,8 \\
\hline \multicolumn{2}{|l|}{ Jumlah total } & 37 & 100 \\
\hline
\end{tabular}

Merujuk dari data 4.3 diketahui bahwa sebanyak 15 siswa yang tuntas dan 22 siswa yang belum memenuhi standar kelulusan penilaian dalam pembelajaran menulis teks pantun pantun. Berdasarkan data hasil tes formatif menulis teks pantun dapat diketahui persentase ketuntasan klasikal dalam pembelajaran menulis teks pantun. Persentase ketuntasan belajar klasikal mencapai $40,55 \%$ belum memenuhi indikator keberhasilan yang ditentukan yaitu $80 \%$. Persentase ketuntasan belajar klasikal perlu diperbaiki pada siklus II, diharapkan indikator keberhasilan tuntas secara klasikal dapat tercapai.

Hasil belajar siswa pada siklus II merupakan hasil tes dalam keterampilan menulis teks pantun siswa. Peneliti menilai hasil belajar menulis siswa dinilai meliputi a) isi pantun b) pesan yang terdapat dalam pantun c) Penulisan tata bahasa d) Kesesuaian topik, e) pengelompokan kata. Siswa yang mengikuti tes pada siklus 1 berjumlah 37 siswa. Hasil belajar siswa dapat dilihat pada tabel di bawah ini

Tabel 3 Rekapitulasi hasil tes formatif siklus II menulis Pantun

\begin{tabular}{|l|l|l|l|l|l|}
\hline No. & Kategori & Skor & $\begin{array}{l}\text { Fre } \\
\text { kue } \\
\text { nsi }\end{array}$ & $\begin{array}{l}\text { Jumla } \\
\text { h Nilai }\end{array}$ & $\%$ \\
\hline 1 & $\begin{array}{l}\text { Sangat } \\
\text { baik }\end{array}$ & $\begin{array}{l}90- \\
100\end{array}$ & - & - & - \\
\hline 2 & Baik & $\begin{array}{l}76- \\
89\end{array}$ & 20 & 1612 & $\begin{array}{l}54,05 \\
\%\end{array}$ \\
\hline 3 & Cukup & $\begin{array}{l}68- \\
75\end{array}$ & 17 & 1260 & $\begin{array}{l}45,95 \\
\%\end{array}$ \\
\hline 4 & Kurang & $0-67$ & - & - & - \\
\hline \multicolumn{2}{|l|}{ Jumlah } & & 37 & 2872 & 100 \\
\hline
\end{tabular}

Berdasarkan data tabel 4.4 terdapat $20(54,05 \%)$ siswa termasuk dalam kategori baik dan ada 17 (45,95\%)siswa 
yang termasuk dalam kategori cukup dan tidak ada siswa yang masuk kategori kurang. Nilai rata-rata kelas pada siklus II sudah memenuhi indikator keberhasilan yang ditentukan yaitu rata-rata kelas $\geq 67$. Nilai rata-rata kemampuan menulis teks pantun sudah meenuhi KKM yang mencapai nilai rata-rata 77,61. Berdasarkan data di atas, dapat dikatakan pada siklus II dapat dikatakan memuaskan. Nilai belajar menulis narasi pada siklus II telah menunjukkan hasil yang diharapkan. Masalah menulis narasi dianggap telah terpecahkan pada siklus II, maka tidak perlu ada tindakan siklus III

Tabel 4 Hasil Analisis Ketuntasan

Belajar Siswa Kelas V B Siklus II

\begin{tabular}{|l|l|c|c|}
\hline No & \multicolumn{1}{|c|}{ Kategori } & Jumlah & $\%$ \\
\hline 1 & Tuntas & 33 & 89,18 \\
\hline 2 & $\begin{array}{l}\text { Belum } \\
\text { Tuntas }\end{array}$ & 4 & 10,81 \\
\hline \multicolumn{2}{|l|}{ Jumlah total } & 37 & 100 \\
\hline
\end{tabular}

Merujuk dari data 4.4 diketahui bahwa sebanyak 33 siswa yang tuntas dan 4 siswa yang belum memenuhi standar kelulusan penilaian dalam pembelajaran menulis teks pantun pantun. Berdasarkan data hasil tes formatif menulis teks pantun dapat diketahui persentase ketuntasan klasikal dalam pembelajaran menulis teks pantun sebesar 89,18 \%. Berdasarkan persentase pada tabel 4 diketahui bahwa pembelajaran menulis teks pantun sudah tergolong tuntas dan mengalami peningkatan.

Hasil penilaian perencanaan pembelajaran pada siklus I pertemuan 1 ini menunjukkan bahwa skor total adalah 48 dan skor maksimal 70 sehingga hasil hitung dengan persentase adalah 68,81. Jadi masih menunjukkan rendah atau harus dilakukan perubahan pada perencanaan berikutnya. Merujuk dari hasil penilaian perencanaan pembelajaran guru pada siklus I pertemuan pertama diperolah nilai 68,57, ini menunjukkan nilai pencapaian masih dalam kategori rendah. Pada siklus I pertemuan kedua diperoleh nilai 75,71 yang menunjukkan adanya perbaikan yang dilakukan oleh guru dalam proses perencanaan pembelajaran.

Pada siklus 1 pertemuan 1 masih banyak yang mendapat skor 3 dan skor 4 , belum ada yang mendapatkan skor 5 . Pertemuan 2 pada siklus pertama masih ada yang mendapatkan skor 3 dan banyak aspek dengan skor 4, dan belum ada yang mendapat skor 5 .

Berdasarkan nilai perolehan pada siklus I dalam pertemuan pertama dan kedua perlu dilakukan adanya perbaikan dalam pembelajaran. Sehingga perlu dilakukan perbaikan pada siklus II.

Merujuk dari hasil penilaian perencanaan pembelajaran guru pada siklus II pertemuan pertama diperoleh nilai 90, pada siklus kedua pertemuan kedua diperoleh nilai sebesar 95,71. Terdapat skor 4 dan skor 5 dari hasil penilaian perencanaan pembelajaran guru. Berdasarkan hasil yang telah diperoleh menunjukkan bahwa penilaian perencanaan pada siklus 2 sudah maksimal.

Hasil observasi pada siklus I pertemuan 1 ini menunjukkan bahwa skor total pelaksanaan pembelajaran yang dilakukan guru adalah 69,54. Jadi masih menunjukkan masih rendah. Masih banyak yang mendapat skor 3 dan skor 4, belum ada yang mendapat skor 5. Hal ini menyebabkan hasil belajar menulis pantun masih belum maksimal. Oleh karena itu, perlu dilakukan perbaikan ada pembelajaran kedua.

Hasil observasi pada siklus I pertemuan 2 ini menunjukkan bahwa skor 
total pelaksanaan pembelajaran yang dilakukan guru adalah 74,09 jadi masih menunjukkan sedang. Masih banyak yang mendapat skor 3 dan skor 4 tetapi sudah ada beberapa aspek yang mendapat skor 5 . Hal ini menyebabkan hasil belajar menulis pantun masih perlu ditingkatkan lagi. Oleh karena itu, perlu dilakukan perbaikan pada pembelajaran siklus II.

Hasil observasi pada siklus II pertemuan 1 menunjukkan bahwa skor pelaksanaan pembelajaran 87,27. Jadi masih menunjukkan cukup. Sudah tidak ada aspek yang mendapat skor 3. Tetapi sudah banyak yang mendapat skor 4 tetapi sudah ada beberapa aspek yang mendapat skor 5. Hal ini menunjukkan hasil belajar menulis pantun masih perlu ditingkatkan lagi. Oleh karena itu, perlu dilakukan perbaikan pada pembelajaran siklus II pertemuan 2.

Hasil observasi pada siklus II pertemuan 2 menunjukkan bahwa proses pelaksanaan pembelajaran yang dilakukan guru adalah 91,36. Jadi menunjukkan baik sekali. Sudah tidak ada aspek yang mendapat skor 3. Tetapi sudah banyak yang mendapat skor 4 dan beberapa aspek yang mendapat skor 5. Hal ini menunjukkan proses pembelajaran menulis pantun sudah maksimal. Oleh karena itu, pada pembelajaran siklus II pertemuan 2 ini diakhiri.

\section{KESIMPULAN}

Berdasarkan hasil penelitian dan pembahasan bagian sebelumnya, maka dapat disimpulkan sebagai berikut.

Perencanaan pembelajaran tematik menulis pantun dengan pendekatan scientific pada tema "Organ Peredaran Darah Hewan dan Manusia" di Kelas V SDN 002 Samarinda Semester Ganjil Tahun Ajar 2016/2017 bisa diefektifkan dengan proses perbaikan pada bagianbagian yang masih lemah. Hasil analisis/penilaian menunjukkan bahwa perencanaan pembelajaran siklus I pertemuan 1 adalah 68,57. Pada siklus I pertemuan 2 adalah 75,71. Pada siklus II pertemuan 1 adalah 90,00. Pada siklus II pertemuan 2 adalah 95,71.

Pelaksanaan pembelajaran tematik menulis pantun dengan pendekatan scientific pada tema "Organ Peredaran Darah Hewan dan Manusia" di Kelas V SDN 002 Samarinda Semester Ganjil Tahun Ajar 2016/2017 bisa diefektifkan dengan perbaikan proses pembelajaran siklus I ke siklus II. Hasil observasi pelaksanaan pembelajaran menunjukkan bahwa pada siklus II pertemuan 1 dengan skor 87,27. Pada siklus II pertemuan 2 dengan skor 91,36.

Hasil belajar Tematik Menulis Pantun Dengan Subtema "Peredaran Darahku Sehat" dengan Pendekatan Sceintific Pada Siswa Kelas V Sdn 002 Samarinda Tahun Pembelajaran 2016/2017 meningkat. Peningkatan tersebut terbukti pada hasil belajar kognitif, afektif, dan psikomotorik sebagai berikut. (a) Hasil belajar afektif Siklus I diperoleh dengan rata-rata sebesar 68,24 dengan kriteria kurang dan siklus II rata-rata sebesar 83,61 dengan kriteria baik sekali . (b) Hasil belajar kognitif Siklus I diperoleh rata-rata 68,97 dengan keriteria kurang dan siklus II rata-rata sebesar 76,32 dengan kriteria baik. (c) Hasil belajar Psikomotor siklus I diperoleh dengan rata-rata 55,33 dengan keriteria kurang dan silus II rata-rata sebesar 74,99 dengan kriteria baik.

\section{DAFTAR PUSTAKA}

Dalman. 2015. Keterampilan Menulis. Jakarta: Rajawali Press 
J.B. Heaton, Writing English Language test (New York: Longman, 1975), hlm. 127

Suroto, 1989. Teori dan Bimbingan Apresiasi Sastra Indonesia. Jakarta: Erlangga.

Suryaman, M, \& Wiyatmi. (2012). Puisi Indonesia. Yogyakarta: Penerbit Ombak

Tarigan, Henry Guntur. 2008. Menulis Sebagai Suatu Keterampilan Berbahasa. Bandung: Angkasa 